\title{
Repercussão da sentença penal na esfera administrativa.
}

\author{
J. Cretella Juinior \\ Professor Titular de Direito Administrativo \\ da Faculdade de Direito da Universidade \\ de São Paulo.
}

\begin{abstract}
1. O probbema. 2. Ilicito administrativo e ilicito penal. 3. Traços do julgamento administrativo. 4. Traços do julgamento penal. 5. Comunicabilidade de instâncias. 6. A sentença penal absolutória. 7. Repercussão da sentença penal absolutória. 8. Não-repercussão da sentença penal absolutória. 9. Doutrina estrangeira. 10. Doutrina brasileira. 11. Jurisprudéncia pätria. 12. Reintegração. 13. Readmissão. 14. Conclusões.
\end{abstract}

\section{O problema.}

Inúmeras vezes o funcionário público é submetido a dois julgamentos, o administrativo, processado perante agentes indicados pela própria Administração, o Judiciário, que se desenrola diante do magistrado do Poder Judiciário, no juízo penal. As decisões das duas esferas podem coincidir, mas pode ocorrer a hipótese inversa, ou seja, que haja "absolvição no juízo administrativo e condenação no juízo penal", ou que haja "absorvição no juízo penal e condenação no juízo administrativo"

Tal diversidade de julgamentos conclusivos é possível, porque a configuração do ilícito administrativo, que permite a condenação, na esfera do Poder Executivo, é diferente da configuração do ilícito penal, que possibilita a condenação, na esfera do Poder Judiciário.

A existência dos dois tipos de ilícitos, de índoles diversas, possibilita igualmente a dupla condenação - a adminis- 
trativa e a penal -, pelo mesmo fato incriminado, sem que se infrinja a regra do "non bis in idem"

Na prática, o que se observa com mais freqüência é a "absolvição no juízo criminal e a condenação no juízo administrativo" Aquilo que é bastante para a incriminação administrativa é, muitas vezes, insuficiente para a delineação da figura penal, base de condenação. O funcionário é absolvido penalmente.

Nesses casos, com o título absolutório, expedido pelo juízo penal, pleiteia o funcionário seu regresso ao cargo, mediante o instituto da reintegração.

Equaciona-se, no caso, o clássico problema da comunicabilidade de instâncias ou da possibilidade de repercussão de pronunciamento de um juízo sobre outro.

Tal problema é paralelo ao que ocorre entre os juízos cível e penal, quando, então, se costuma indagar: qual a repercussão, no cível, da sentença penal, transitada em julgado?

Substituindo-se os vocábulos civil - cível, empregados no Código Civil e no Código de Processo Penal, por administrativo, são válidos os preceitos desses Códigos, para o nosso caso. "A responsabilidade civil é independente da criminal; não se poderá, porém, questionar mais sobre a existência do fato, ou quem seja seu autor, quando estas questões se acharem decididas no crime" (Código Civil, art. 1525) "Faz coisa julgada no cível a sentença penal que reconhecer ter sido o ato praticado em estado de necessidade, em legítima defesa, em estrito cumprimento do dever legal ou no exercício regular de direito" (Código de Processo Penal, art. 65) "Não obstante a sentença absolutória no juízo criminal, a ação civil poderá ser proposta quando não tiver sido, categoricamente, reconhecida a inexistência material do fato" (Código de Processo Penal, art. 66) .

O artigo 386 do Código de Processo Penal e seus incisos fornecerão também subsídios para a resolução do problema. 
Existe autonomia total entre as esferas administrativa e penal ou são elas comunicáveis de tal modo que decisões do juízo penal possam influir na órbita administrativa? A absolvição, no juízo criminal, influi sempre sobre a decisão administrativa que conclui pela culpabilidade do funcionário, aplicando-lhe, em consequiência, pena concernente à falta cometida? Em que casos a absolvição no juízo criminal repercute na instância administrativa?

\section{Ilícito administrativo e ilícito penal.}

No campo do direito, o ilícito alça-se à altura de categoria jurídica e, como entidade categorial, é revestida de unidade ôntica, diversificada em penal, civil, administrativa, apenas para efeitos de integração, neste ou naquele ramo, evidenciando-se a diferença quantitativa ou de grau, não a diferença qualitativa ou de substância. Desse modo, o ilícito administrativo caminha em plano menos elevado do que o ilícito penal, é um minus, em relação a este, separando-os o matiz de oportunidade e de conveniência, avaliado pelo critério axiológico, possível na esfera discricionária do administrador e do magistrado, contingente ao tempo e às áreas geográficas.

O ilícito é sempre um fato não permitido, proibido pela lei, concretizando-se ora no delito civil - fato ilícito, danoso, cometido com intenção de prejudicar, ora no delito penal ato humano, anti-jurídico, doloso ou culposo, sancionado por uma pena - ora no delito administrativo, ação ou omissão do agente público, que causa perturbação aos serviços públicos, ou atenta contra a hierarquia. Tanto são diversos os ilícitos, penal e administrativo, que já se decidiu: "existe substancial diferença entre a pena criminal e a pena administrativa, podendo esta perdurar quando anulada aquela" (STF, em RDA 75/171)

3. Traços do julgamento administrativo.

O julgamento administrativo desenrola-se no âmbito da Administração. Quando esse julgamento é referente à apura- 
ção de irregularidades funcionais, seu término converge para uma tomada de posição do administrador, concretizando-se na edição do ato administrativo.

Daí, definir-se o processo administrativo, quer disciplinar, quer penal como a série de procedimentos ou opєrações, que antecede a edição do ato administrativo. $\mathrm{O}$ ato administrativo, que consubstancia, por exemplo, uma penalidade, é fundamentado nas operações preliminares processuais (cf. nosso Tratado de direito administrativo, vol. VI, 1969, págs. 61-62)

No entanto, mesmo com a medida processual acautelatória, que é o processo administrativo, a Administração pode cometer injustiças ou praticar atos irregulares.

Para isso, nos sistemas jurídicos, como o nosso, o ato administrativo, eivado de ilegalidade, ou o processo administrativo, viciado. por defeito de forma, é suscetível de revisão pelo Poder Judiciário.

E que, no âmbito da Administração, existe aquilo que ORLANDo denominou com muita propriedade de "espírito de corporação", o que desnatura, não raro, os atos e processos do Poder Executivo (Orlando V E., Principii di diritto amministrativo, 5. a ed., 1919, pág. 340)

O julgamento administrativo, consubstanciado, no processo administrativo, desenvolve-se, muitas vêzes, em ambiente de tensão, carregado de paixões, faltando-lhe a necessária serenidade para a apreciação valorativa dos fatos. As pressões administrativas e políticas sobre os membros das Comissões Processantes influem, inúmeras vezes, nas decisões.

Tratando-se da apuração de fato capitulado como crime - Crime contra a Administração -, configura-se o processo administrativo penal, que definimos como "o conjunto ordenado de formalidades, praticadas na esfera administrativa, a que é submetido o servidor público que cometeu crime contra a Ad- 
ministração" (cf. nosso Tratado de direito administrativo, 1969, vol. VI, pág. 193) .

\section{Traços do julgamento penal.}

Tratando-se de crime, a autoridade que determinar o processo administrativo providenciará a instauração de inquérito policial (art. 226, do Estatuto dos funcionários civis da União, de 1952), ou, na linguagem do Estatuto dos funcionários civis do Estado de São Paulo, art. 304: "Quando ao funcionário se imputar crime, praticado na esfera administrativa, a autoridade que determinou a instauração do processo administrativo providenciará para que se instaure, simultaneamente, o inquérito policial"

Estando capitulada a infração, na lei penal, o processo será remetido à autoridade competente, ficando traslado na repartição.

Com o ato da remessa passa o processo administrativo criminal para a esfera penal, continuando, entretanto, vinculado à esfera administrativa, esperando-se, posteriormente, o resultado da sentença criminal, absolutória ou condenatória, para, conforme o caso, reviver-se ou não o resultado a que se chegou no juízo administrativo.

Remessa é o ato concreto pelo qual se estabelece a relação entre a instância administrativa e a instância penal, surgindo, no âmbito do direito administrativo, o relevante problema da comunicabilidade de instâncias.

Remetida a peça processual administrativa para a esfera penal, o novo julgador vai estudá-la sob todos os aspectos, tomando as medidas necessárias para o fundamento de sua decisão. Recebendo os autos do processo administrativo, o juiz do crime decide de acordo com as provas dos autos.

Livre de pressões de qualquer espécie, forma sua convicção de maneira objetiva e rápida. 
A probabilidade de não condenar injustamente é muito maior na esfera penal do que na administrativa.

\section{Comunicabilidade de instâncias.}

A comunicabilidade de instâncias ou interdependência dos juízos administrativo e penal é da mais alta importância, devendo, entretanto, entender-se em seus justos termos.

Não deve tal interdependência ocorrer sempre, como também a teoria da independência das jurisdições será compreendida nos casos particulares em que se verifica.

O pronunciamento de autoridade do Estado, quer do Poder Executivo, quer do Poder Judiciário, deveria ser, de preferência, uniforme, para que a diversidade de decisões não concorresse para o desprestígio de um dos Poderes e, em última análise, do próprio Estado.

"Deve haver entre as instâncias um entendimento que permita alcançar a verdadeira justiça, o que nem sempre acontece quando se defende uma autonomia absoluta que só prevalece quando mal compreendida a independência das jurisdições. Tão ortodoxamente certos defensores da independência dos poderes situam a questão que, mesmo no seio do Judiciário, há quem proclame - e, muitas vezes, prevalece seu ponto de vista - que é defeso à justiça apreciar o mérito dos processos administrativos, donde limitar-se sua apreciação ao que chamam legalidade do processo. A legalidade, em tal entender, limita a ação jurisdicional ao exame do aspecto formal do processo. Assim, por exemplo, em caso de demissão de funcionário, competiria ao Judiciário unicamente indagar se a demissão teria sido precedida de inquérito administrativo e se, neste inquérito, foi dada ao funcionário oportunidade de defesa, requisitos essenciais que seriam suficientes para justificar o ato demissório "(Melo Couto Anibal, Da responsabilidade do servidor público, em RDA 37/510-511)

Tão comunicáveis são as esferas penal e administrativa 
que, em certo momento, o DASP se inclinou pela tese da necessidade do prévio pronunciamento do Poder Judiciário para aplicação da pena administrativa, visto que entre as infrações que podem dar motivo à pena de demissão a bem do serviço público se inclui a infração criminal, o crime (Exposição de Motivos do Dasp n. ${ }^{\circ} 882$, de 23 de março de 1943)

Realmente, se o juízo administrativo decide uma coisa e o juízo penal decide outra, em matéria de crime, tal disparidade de soluções concorre para desacreditar um dos julgadores.

Por isso, melhor seria que, tratando-se de crime, o juízo administrativo sobrestasse seu pronunciamento, aguardando a decisão do Poder Judiciário.

Nos vários Estatutos dos Funcionários, quer da União, Estados ou Municípios, a referência a crimes contra a Administração é clara. Capitulam-se depois, especificamente, inúmeras figuras definidas também, no Código Penal, como crimes.

Ora, os dispositivos estatutários, quando falam em crime, não definem os atos infringentes da lei penal e, por isso, só à esfera judiciária competente é que cabe definir o delito, já que os crimes não são punidos pela Administração pelo fato de constituirem crimes, mas por estarem definidos de maneira autônoma no Estatuto (RDA 51/190)

Em que casos se impõe a comunicabiliciade de instâncias? Em que hipóteses a decisão administrativa - verdadeira sentença administrativa - adquire foros de res judicata, de intangibilidade, a ponto de ser irreformável pelo Poder Judiciário?

\section{A sentença penal absolutória.}

$\mathrm{Na}$ sentença penal absolutória, a parte dispositiva mencionará a causa da decisão, desde que reconheça a presença ou ausência de elementos, suficientes para tal pronunciamento.

O Código de Processo Penal Brasileiro, em seu artigo 
386, enuncia seis causas distintas, que levam o magistrado a absolver o réu. Êste artigo servirá de roteiro seguro para a resolução do importante tema da comunicabilidade dos juízos penal e administrativo. Assim: I - estar provada a inexistência do fato; II - não haver prova da existência do fato; III não constituir o fato infração penal; IV - não existir prova de ter o réu concorrido para a infração penal; VI - não existir prova suficiente para a condenação.

Tudo gira, pois, em tôrno do fato, existência ou inexistência. Ou da prova da existência do fato. Ou da capitulação do fato como infração penal. Ou da suficiência ou insuficiência de provas para a condenação. Ou ainda da existência de circunstância que exclua o crime ou isente o réu de pena.

\section{Repercussão de sentença penal absolutória.}

Admitamos que o funcionário público, acusado de crime de peculato, é submetido a processo administrativo e, em consequiência, demitido a bem do serviço público.

Peculato é a apropriação, pelo funcionário, de dinheiro, valor ou qualquer outro bem móvel, público ou particular, de que o agente tem a posse em razão do cargo (Art. 312 do Código Penal de 1940) Desvio desses bens, em proveito próprio ou alheio, também configura o crime de peculato. Peculato doloso.

A ação do funcionário deverá recair sobre bem móvel, do Estado ou de particular, desde que tenha a guarda do objeto.

Na hipótese formulada, o juiz do processo penal, tendo convertido o julgamento em diligência, verificou que os valores não tinham sido subtraídos. O dinheiro, um pacote de notas, caíra atrás de um móvel; ou, noutro caso, os objetos artísticos do museu, sob a guarda de funcionário, tinham sido transportados para o andar superior para reparos, ou para salvá-los de inundação iminente. 
Em qualquer dos casos apontados, tendo ficado reconhecida a inexistência do fato, suporte indispensável para a configuração do crime, ilustra-se a primeira hipótese enumerada no Código de Processo Penal: "estar provada a inexistência do fato".

Admitamos, num outro caso, que funcionário bibliotecário seja acusado de ter-se apropriado dos livros confiados à sua guarda. Colegas acusam-no do fato. Em consequiência, é demitido do cargo, depois da instauração do processo administrativo.

Nenhum livro, entretanto, é encontrado com o funcionário. Não se conseguiu provar, em momento algum, que o agente se apropriou dos livros.

No mundo dos fatos, pode mesmo ter ocorrido o desaparecimento dos livros, mas o fato do apresamento, pelo funcionário, não foi provado, nem direta, nem indiretamente.

Hipótese análoga pode ser aventada para o carteiro, acusado de desvio de registrados com valores, confiados à sua guarda. No entanto, nenhuma reclamação por parte do público; nenhum valor encontrado em poder do carteiro. As acusações constantes do inquérito administrativo, vagas e imprecisas, levadas depois para o juiz criminal ilustram a segunda hipótese enumerada no Código de Processo Penal: "não haver prova da existência do fato".

Figuremos, agora, o caso de porteiro de repartição pública, acusado de ter aberto a porta, possibilitando que terceiros entrassem no prédio e furtassem valores do Estado, ou de particulares, mas sob a guarda de agentes do poder público.

Realmente, a porta fora aberta, mas não existe prova da abertura pelo porteiro. Ou, então, a porta fôra aberta para que outro funcionário entrasse e, então, nesse meio tempo, outros entraram. 
Tendo o juiz penal concluído "não existir prova de ter o réu concorrido para a infração penal", temos configurado a IV hipótese do Código de Processo, art. 386.

Em todos os casos exemplificados, a sentença penal absolutória repercute no juízo administrativo, sobrepondo-se à decisão das autoridades administrativas, ou seja: a) quando fica provada a inexistência do fato; b) quando não há prova da existência do fato; c) quando não existe prova de que o funcionário concorreu para a infração penal.

\section{Não-repercussão da sentença penal absolutória.}

Com base nos outros incisos do art. 386 do Código de Processo Penal, procuremos figurar as hipóteses em que a sentença penal absolutória não se reflete na esfera administrativa.

O mesmo artigo 386 fornece-nos a chave para a resposta em seus incisos III e IV, isto é, quando o fato não constitui infração penal e quando não existe prova suficiente para a condenação.

Nesses dois casos, quando o fato não configura infração penal e quando a prova do fato é insuficiente ou ineficiente, prevalece a decisão administrativa.

A configuração da primeira hipótese é simples. Basta que se pense em falta disciplinar e não em crime.

Se a falta cometida pelo agente público, por ação ou omissão, ferir simplesmente o interesse do serviço público, perturbando-lhe o funcionamento ou afetando, atual ou potencialmente, sua eficiência, daí nasce a responsabilidade disciplinar do funcionário (Fonseca Tito Prates da, Lições de direito administrativo, 1943, pág. 189) Ação ou omissão do funcionário que implique quebra de dever do cargo pode levar à penalidade de caráter administrativo, destinada a corrigi-lo ou a afastá-lo do serviço público, sem que tenha força, porém, de incriminá-lo penalmente. 
Não se confunde, pois, a responsabilidade administrativa com a responsabilidade penal, consistindo a primeira na tutela do bom funcionamento do serviço público e dos fins por ele visados. O delito penal, ao contrário, tem delineamento preciso, disciplinado por um texto legiṣlativo ao qual se dá interpretação restritiva.

No campo disciplinar, tal precisão não existe. A falta dis. ciplinar é atípica. Deixa-se uma larga margem para poder atingir-se, pela repressão disciplinar, toda infração aos deveres e obrigações do funcionário.

Não é necessário um elenco exaustivo para as faltas disciplinares, como há para os crimes. Nem se requer uma definição geral e precisa, estabelecida por um texto.

Não tendo guarida, no campo disciplinar, o princípio do nullum crimen, nulla poena sine lege, resta grande margem ao superior hierárquico para, discricionariamente, determinar e apreciar a falta disciplinar.

A ausência de tipicidade nas faltas disciplinares não indica, entretanto, que a ação administrativa se realiza de modo arbitrário ou injurídico. A lei estabelece critérios dentro dos quais a responsabilidade disciplinar é apurada e graduada, à luz dos cânones gerais do direito.

As penas criminais são estabelecidas em textos de lei, nunca em regulamentos e, ao contrário das penas disciplinares, são fixadas em textos de interpretação restrita.

Ao passo que as sanções administrativas são fixadas por autoridades administrativas, em processos administrativos, as sanções penais são fixadas por juízes togados, em processo penal. A falta penal é típica.

A aplicação da pena disciplinar não exige previsão expressa, em lei, não se sujeitando à idéia de tipicidade prévia. Embora haja tendência doutrinária a prestigiar o trabalho das co- 
missões processantes, o superior hierárquico tem enorme poder para determinar e apreciar a falta disciplinar.

Por outro lado, os crimes funcionais constituem quase sempre faltas disciplinares, mas a recíproca não é verdadeira.

Desse modo, inúmeras vezes o fato não configura infração penal, não é crime. Nesse caso, o agente público é absolvido na esfera penal. No entanto aquilo que não é crime, pode ser falta funcional, falta disciplinar, o que tem, como efeito, a condenação administrativa. Absolvido penalmente, é condenado administrativamente. Há incomunicabilidade de instâncias, porque a decisão do juiz togado não repercute na esfera administrativa.

A segunda hipótese de não-repercussão temos na insuficiência ou ineficiência de provas.

Com efeito, "a absolvição por ineficiência, deficiência ou insuficiência de provas não tem influência igual à da absolvição pela inexistência material do fato, ou por não ter sido o funcionário seu autor, no tocante à instância administrativa" (RDA 51/191).

Por isso se diz de modo genérico que a absolvição em processo penal não invalida, por si só, a demissão de funcionário contra o qual figura a infração disciplinar. Ou mesmo infração penal. À condenação criminal impõe-se rigor bem maior do que para a aplicação de pena administrativa. A prova que é suficiente, no âmbito administrativo, para demissão, não é bastante, na esfera penal, para a condenação (Revista de Direito da Procuradoria Geral da Guanabara, 1956, 4/267)

Quando a absolvição, no juízo penal, repousa, apenas, em pressupostos ligados ao maior ou menor poder de convicção da prova coligida, nenhum efeito poderá ter sobre a punição administrativa. Se a prova é frágil, mas existe. Se a prova é insuficiente ou deficiente, mas existe, se a prova foi colhida em processo administrativo regular, sem defeitos formais, com 
possibilidade de ampla defesa, o ato administrativo demissório subsiste, é indestrutível, a despeito da absolvição no juízo criminal.

Logo, não há repercussão da sentença penal absolutória fundada em infração penal não configurada e em ineficiência de prova. Ocorre a incomunicabilidade de instância, erigindose a decisão administrativa em "res judicata"

\section{Doutrina estrangeira.}

Os autores estrangeiros têm dedicado a maior atenção ao tema da comunicabilidade de instâncias.

Marcel Waline acentua que "o julgamento penal não subordina a autoridade investida do poder disciplinar, a não ser na medida em que afirma a existência ou a inexistência material do fato incriminado, mas uma absolvição pode significar apenas que os fatos apurados não reunem os elementos de um delito, podendo, entretanto, configurar uma falta disciplinar" (Traité élémentaire de droit administratif, 6. ${ }^{\mathrm{a}}$ ed., 1952, pág. 352)

"A regra non bis in idem, em virtude da qual um indivíduo não pode ser processado e punido duas vezes pelo mesmo fato, encontra plena aplicação em matéria penal e em matéria disciplinar, cada uma considerada separadamente, mas não vigora nas relações da repressão disciplinar e da repressão penal, pela simples razão de que não há idem necessário para a aplicação da regra. A repressão disciplinar é diferente da repressão penal. Logo, o processo penal não impede a possibilidade do processo disciplinar e vice-versa; o fato de haver o funcionário sido condenado penalmente não impede aplicação de uma sanção disciplinar. Dois casos, a respeito, devem ser considerados: a) o juiz penal absolve o funcionário porque os fatos a ele atribuídos, materialmente estabelecidos, não caem sob a qualificação de um delito penal. O processo disciplinar é possível, mas a verificação dos fatos, feita pelo juiz penal, vincula o órgão disciplinar. Resta decidir se esses fatos são ou não 
de molde a acarretar a sanção disciplinar; b) o juiz penal absolve porque os fatos atribuídos ao funcionário não são materialmente apurados. Processo administrativo disciplinar, fundado sobre os mesmos fatos, não é mais possível. A autoridade da coisa julgada se opõe a isso. Para processar é necessário encontrar fatos novos atribuíveis ao funcionário (Duez Paul e Debeyre Guy, Traité de droit administratif, 1952, pág. 688) .

"Pelo fato de a infração disciplinar ter caracteres próprios que a tornam diferente da infração penal, decorre disso a independência recíproca das duas repressões, a disciplinar e a penal. E assim que a repressão disciplinar pode intervir simultâneamente com a penal, porque o fato pode ter, ao mesmo tempo, a qualidade de infração disciplinar e de infração penal, justificando a coexistência das duas repressões. Por outro lado, a repressão disciplinar pode intervir depois do arquivamento ou da absolvição no juízo penal, porque um fato pode não ser infração penal e constituir, entretanto, infração disciplinar" (Bonnard Roger, Précis de droit administratif, 1935, pág. 396)

"Se a repressão disciplinar é, sem dúvida alguma, uma repressão, ela não se confunde nunca com a repressão penal. Esta diz respeito não importa a quem (porque abrange, naturalmente, os funcionários, mas não somente estes), intervém nos fatos qualificados de infrações, que não são vinculados ao exercício de uma função e comporta sanções que atingem o delinqüente, não em sua função, mas em sua vida, liberdade ou propriedade. A diferença de natureza entre as duas repressões tem por efeito a independência entre ambas, independência que fica bem clara quando se observa que numerosas condutas podem constituir infrações disciplinares sem serem infrações penais e inversamente. Assim, quando um funcionário é processado, por um só e mesmo fato, na esfera penal e na esfera administrativa, a decisão de uma das duas instâncias não vincula a outra, mas o alcance desta afirmação deve ser demarcado. A decisão da autoridade administrativa, em hipótese alguma, 
nunca, vincula a decisão do juiz penal. Por sua vez, a decisão do juiz penal deixa livre a autoridade disciplinar se o juiz penal conclui que o fato incriminado não constitui infração penal, visto que precisamente um fato pode ser infração disciplinar sem ser infração penal. Entretanto, as verificações feitas pelo juiz penal e concernentes à existência ou inexistência material dos fatos, vinculam, em princípio, a autoridade disciplinar. A autoridade administrativa, porém, não se acha vinculada às decisões penais que absolvem, por motivo de dúvida "(LAubadère André de, Traité élémentaire de droit administratif, 3. ${ }^{\mathrm{a}}$ ed., 1963, vol. II, pág. 92)

Tratando da exatidão material dos motivos de fato, ressalta JEAN Rivero que "se o fato, sobre o qual o ato declara se fundamentar, não se produziu, o ato, na ausência do motivo legal, perde sua justificativa. Por exemplo, se um funcionário é punido com sanção disciplinar por motivos que, na realidade, não existiram, a sanção repousa em motivo materialmente inexato e, portanto, sob tal aspecto, ilegal "(Rivero Jean, Droit administratif, 5. a ed., 1971, pág. 241)

"No caso em que o juízo penal concluir pela absolvição, deve entender-se que tal sentença preclui o curso da ação disciplinar apenas quando se pronunciou pela inexistência do fato ou porque o funcionário nele não haja tomado parte, ao passo que qualquer outra forma absolutória não pode impedir o exercício do poder disciplinar da Administração, diversa sendo, subjetivamente, a valoração que dos mesmos fatos deve fazer o juiz administrativo e o juiz penal "(Piromallo Francesco, Disciplina della Publica Amministrazione, em Nuovo Digesto Italiano, 1938, vol. V, pág. 28, "sub voce")

"A absolvição no juízo penal constitui autoridade de coisa julgada, quando declara a inexistência do fato ou quando, embora admitindo o fato, exclui do fato a participação do indiciado, não obstante, nessas hipóteses, possam surgir fatos particulares e circunstâncias disciplinarmente puníveis “( $\mathrm{PE}$ - 
Trozziello Modestino, Il rapporto di pubblico impiego, 1935, pág. 264)

Sistematizando o tema, Alessio aponta os princípios que regem a comunicabilidade e a incomunicabilidade de instâncias. "1. Influência do processo administrativo sobre o penal. a) A comunicação de punição disciplinar não exclui nunca a responsabilidade penal, quando tal ocorre. Nem pode haver influência alguma sobre o juízo penal, no que se refere ao acertamento do fato. b) A absolvição administrativa não exime de responsabilidade penal, nem quando se está diante da exclusão do elemento objetivo da falta. O processo administrativo não tem caráter jurisdicional e, pois, as decisões com que ele se encerra não podem, em caso algum, adquirir força de coisa julgada, nem a favor e nem contra o empregado. $2 .^{\circ}$ Influência do juízo penal sobre o disciplinar. a) Deve ser imediatamente suspenso do cargo e dos vencimentos o funcionário contra o qual se expediu mandado de prisão. b) Quando o fato atribuído ao funcionário tenha dado lugar a denúncia à autoridade judiciária, o processo disciplinar permanecerá suspenso, salvo a obrigação de concorrer para a apuração dos fatos e à colheita das provas. Não se instaurará processo administrativo se o juiz penal decidiu com sentença que exclui a existência do fato imputado ou, embora admitindo-o, exclui o funcionário da autoria (Alessio Francesco D', Istituzioni di diritto amministrativo italiano, 4. ${ }^{a}$ ed., 1949, vol. I, págs. 578579) .

Os tribunais italianos firmaram orientação que assim se resume: a absolvição do funcionário, na esfera penal, preclui a via ao processo administrativo quando a sentença absolutória conclui pela inexistência do fato ou pela exclusão da autoria, ou seja, houve o fato, mas o funcionário não é seu autor. Qualquer outro tipo de absolvição não impede o exercício do poder disciplinar, como ocorre, por exemplo, com a absolvição penal por insuficiência de provas (cf. Alessio Francesco D', Istituzioni, citada, pág. 579 , nota n. $^{\circ}$ 2) 
Também a sentença penal absolutória pode, em alguns casos, excluir o processo disciplinar, o que ocorre quando nessa se decide pela inexistência do fato imputado ou, embora o admitindo, fica provado que o funcionário nele não tomou parte. Em tais hipóteses, a demissão é revogada e o funcionário readquire o direito aos vencimentos não recebidos. Entretanto, se a sentença absolutória, do juízo penal, é pronunciada com fundamento diverso do acima apontado - anistia; insuficiência de provas; porque o fato, embora cometido, não constitui crime, o processo administrativo prevalece (ZANoBInI Guido, Corso di diritto amministrativo, $4 .^{\text {a }}$ ed., 1949, vol. III pág. 249)

E unânime, pois, a doutrina estrangeira quando distingue a inexistência do fato; a existência do fato, mas a exclusão da autoria; c a insuficiência de provas. Nos dois primeiros casos, há repercussão da sentença penal absolutória na esfera administrativa; no segundo caso, não há a repercussão mencionada. prevalecendo o que as autoridades administrativas tinham decidido.

\section{Doutrina brasileira.}

A doutrina brasileira, no tocante à comunicabilidade da instância penal com a civil e administrativa, é unânime (cf. nosso Tratado de direito administrativo, 1969, vol. VI, págs. 199 a 208), orientando-se pelo que fixou a Exposição de Motivos do Código de Processo Penal de 1941: "Não será prejudicial da ação cível a decisão que, no juízo penal: (1) absolver o acusado, sem reconhecer, categoricamente, a inexistência material do fato (2) ordenar o arquivamento do inquérito ou das peças de informação, por insuficiência de prova quanto à existência do crime ou sua autoria (3) declarar extinta a punibilidade ou (4) declarar que o fato imputado não é definido como crime".

Combinando-se o que diz a Exposição de Motivos com o que se acha determinado no artigo 386 , incisos I a VI e com 
o que preceitua o art. 65 do Código de Processo Penal, bem como com o que diz o Código Civil em seu artigo 1.525, tem a doutrina pátria todos os dados para o equacionamento e resolução da influência da sentença penal absolutória sobre tudo o que se decidir nos demais juízos.

\section{Jurisprudência brasileira.}

"Não se poderá questionar mais sobre a existência do fato, ou quem seja o seu autor, quando estas questões se acharem decididas no crime" (Código Civil, artigo 1.525)

Tratando-se de funcionário público, submetido a processo administrativo, que culminou por sua condenação e pela aplicação da pena de demissão, em virtude de crime, cumpre indagar a respeito da influência da sentença penal absolutória sobre o que decidiram as autoridades administrativas.

A lei civil substantiva, depois de afirmar que a responsabilidade civil é independente da responsabilidade criminal, preceitua que a decisão penal é soberana e encerra o assunto em dois casos: quando conclui a respeito da existência do fato e quando conclui sobre a autoria (art. 1.525 do Código Civil)

"Se o fato imputado ao funcionário for um só e o julgado criminal negar a existência desse mesmo fato, ou negar a autoria atribuída no funcionário, forçoso será reconhecer o efeito daquele julgado no cível, até mesmo em obediência à regra do art. 1.525 do Código Civil "( $\mathrm{RF}$ 142/142); porque "não pode subsistir a demissão que teve por causa fato apurado em inquérito administrativo e negado no processo penal" (RDA 27/79); "se o fato que constitui ilícito administrativo é, ao mesmo tempo, ilícito penal, a decisão do juiz criminal, que declara inexistente o fato, ou que o funcionário não foi seu autor, é válida na instância administrativa" (RDA 51/189 e 94/281) ; "fácil é, em nosso direito, aliás, comprovar a justa dependência da instância administrativa à decisão da justiça criminal, quando esta reconhece inexistente o fato ou afirma 
não ter sido, o funcionário, seu autor. A decisão administrativa, no caso, é vinculada à existência de um pressuposto: a prática do fato, punível também na órbita penal. Cabendo ao Poder Judiciário o controle da legalidade dos atos administrativos (e, no exame da legalidade, se compreende o da existência desse fato pressuposto, que justifica a punição), quando o Poder Judiciário tiver de examinar a legalidade do ato impugnado, estará obrigado a respeitar a conclusão da justiça criminal, que declarou inexistente o fato ou que dele não participou o funcionário. E não poderá acolher a legitimidade do ato administrativo que chegou a conclusão diversa. Portanto, deve a administração atender, nesse caso, à conclusão do julgado criminal, por motivo semelhante ao que impõe e acolhe a instância civil" (RDA 51/190)

"Absolvido pela inexistência de crime, sem qualquer valor resulta a demissão de funcionário que se apoiou na prática do ato delituoso" (RDA 58/126), porque "não subsiste a demissão de funcionário acusado de crime do qual foi absolvido, tendo a respectiva sentença negado o fato que lhe foi atribuído" (RDA 26/120)

"A absolvição do funcionário, no processo criminal, não acarreta, necessariamente, a sua reintegração. Somente quando o fato admitido na esfera administrativa for tido como inexistente, no processo judicial, é que o decidido atinge a solução administrativa" (RDA 26/125)

A nossa mais moderna jurisprudência mantém a mesma colocação, decidindo que a sentença penal absolutória influi sobre a decisão administrativa, anulando-a e permitindo a reintegração do funcionário, quando o juízo criminal declara: a) a INEXISTÊNCIA DO FATO - "negada a existência do fato, no juízo criminal, não subsiste a pena administrativa" (STF, em RDA 94/86) : "somente a decisão, na esfera criminal, sobre a negativa do fato imputado, geraria ao funcionário público, demitido pela denúncia da prática de peculato, o direito de pleitear o seu reingresso no funcionalismo, voltando para o lu- 
gar do qual fora alijado" (TJRGS, em RT 412/367) ; "deve ser invalidada, com a consequiente reintegração do servidor, a demissåo fundada em prática de crime que veio a ser considerado inexistente pelo Judiciário" (TFR 221/121) - b) a FALTA DE PROVA DA EXISTÊNCIA DO FATO - "absolvido na instância criminal, por falta de provas, funcionário demitido, acusado de furto, em processo administrativo, deve ser readmitido" (STF, em RDA 97/113) - c) NEGAÇÃO DA AUTORIA - "se o julgado criminal negar a autoria, atribuída ao funcionário, forçoso será reconhecer o efeito daquele julgado no cível" (RF 142/142); "a decisão do juiz criminal, que declara que o funcionário não foi seu autor, é válida na instância administrativa" (94/281)

Logo, a inexistência do fato, a falta de prova da existência do fato e a não vinculação do funcionário à prática do fato, considerado crime, quando fundamento da sentença penal absolutória, fazem com que o julgado criminal influa na esfera administrativa.

Decisões também modernas de nossos tribunais declaram que a falta residual, aquele minus que as autoridades administrativas apuraram, basta para condenar o funcionário, administrativamente, amparado como legítimo e inatacável o ato administrativo demissório. "A absolvição em processo criminal não importa, necessàriamente, em reintegração do funcionário demitido; há que fazer-se o exame sobre a falta residual" (STF, em RDA 97/112) "Pela falta residual, não compreendida na absolvição pelo juízo criminal, é admissível a punição administrativa do servidor público" (Súmula 18) ; "A absolvição por ineficiência da prova não tem influência igual à da absolvição pela inexistência material do fato, ou por não ter sido o funcionário seu autor, no tocante à instância administrativa" (RDA 51/191) "A absolvição, no processo criminal, não invalida, por si só, a demissão de funcionário, contra o qual ficou apurada infração disciplinar" (TFR, em RDA 77/206) "Um fato pode não ser punível na Justiça Penal e se-lo na esfera administrativa, pois a sua gravidade pode não ser bastante para justifi- 
car uma condenação criminal, mas ser suficiente para fundamentar uma pena administrativa" (RDA 37/514)

\section{Reintegração.}

Pela demissão o funcionário é desligado do cargo que ocupava. Não mais pertence aos quadros. E pessoa estranha ao funcionalismo. Perde todo e qualquer direito aos vencimentos e vantagens. Rompe-se com a demissão o vínculo jurídico que une o funcionário fúblico ao Estado.

Por isso, em razão dos prejuízos econômicos e morais advindos, procura o funcionário demitido pleitear seu reingresso ao serviço público.

A reintegração é uma das formas de reingresso ao funcionalismo, consistindo na volta do funcionário ao mesmo cargo que ocupava a do qual fôra ilegalmente demitido, com a conseqüente reparação integral de todos os danos sofridos em razão do afastamento.

Reconhecida a ilegalidade do ato de demissão, em decisão administrativa ou judicial, o funcionário tem o direito subjetivo público de regressar ao serviço, reocupando o cargo, restaurados todos os direitos e vantagens de que ficou privado durante o afastamento (direito ao estipêndio, pagando-lhe o Estado todos os atrasados; direito a férias não gozadas; direito aos quinqüênios; direito à licença-prêmio; direito à aposentadoria, caso tenha completado o tempo de serviço durante o período de afastamento)

No caso que estamos analisando, tem inequívoco direito subjetivo à reintegração o funcionário público que foi demitido, em virtude de processo administrativo, mas que, posteriormente, foi absolvido no processo penal, tendo concluído a sentença penal absolutória que o fato inexistiu, que houve falta de prova da existência do fato, ou que houve o fato, mas outro é seu autor e não o funcionário incriminado. 
Nesses casos, a sentença penal absolutória é título hábil para a reintegração do funcionário, sobrepondo-se à decisão administrativa (RDA 26/125; RF 221/121; RDA 25/92).

A reintegração ou volta do funcionário ao mesmo cargo, ressarcido plenamente dos prejuízos sofridos com o afastamento, é uma das conseqüências da existência da comunicabilidade de instâncias ou de juízos. A sentença penal absolutória repercute no âmbito administrativo, porque não é possível questionar sobre a existência do fato ou sobre quem seja seu autor, na esfera administrativa, quando tais questões se acharem decididas no crime.

A irresponsabilidade penal do funcionário, proclamada no juízo criminal, determina a imediata reintegração do réu no cargo público de que fora demitido (RDA 34/225), sempre que o fato fôr negado, não provado, ou nada tendo o funcionário com o ocorrido; "reintegração é o remédio contra a demissão ilegal. Fundado o ato de demissão, há que examinar a procedência do fundamento e sua conformidade com a legislação aplicada, desde que a apreciação de seu merecimento não contrarie o princípio da harmonia dos poderes" (RDA 25/92).

Voltando ao cargo o funcionário ilegalmente demitido, quem o ocupava perde o lugar, sem qualquer direito à indenização. Tratando-se de primeira investidura, fica destituído de plano; se o ocupante já pertencia aos quadros do funcionalismo e veio de outro cargo, voltará ao cargo que antes ocupava. De qualquer modo, a reintegração, sendo um direito e não uma liberalidade, garante o cargo ao antigo titular.

"Na reintegração do funcionário por sentença judicial, o ocupante do cargo é destituído de plano, sem direito a indenização" (RDA 32/149)

Não ocorre, entretanto, a possibilidade de reintegração, quando o funcionário, demitido em processo administrativo, é absolvido no processo penal, fundamentando-se a sentença penal absolutória na insuficiência ou deficiência de provas. 
Absolvido no juízo penal, não tem o funcionário público o direito subjetivo de pleitear a reintegração, porque restou um resíduo, um minus, suficiente para caracterizar o ilícito administrativo, insuficiente, entretanto, para caracterizar o ilícito penal.

Esse quantum é o bastante para o suporte legal do ato administrativo de demissão.

A incomunicabilidade de instâncias ou juízos é evidente. A sentença penal absolutória não repercute no âmbito administrativo. Exaure-se a sentença penal absolutória em seu próprio âmbito, não o ultrapassando.

A falta residual persiste e justifica a decisão administrativa, erigindo-se como se fosse a "res judicata" administrativa, intangível, inatacável, irreformável.

\section{Readmissão.}

Há várias modalidades de reingresso ao serviço público, distinguindo-se, entre essas vias, a reintegração, a readmissão e a reversão, mas, ao passo que a primeira figura repousa num direito do funcionário, a readmissão está na esfera discricionária da Administração, consistindo num ato de liberalidade, bem como a reversão, tanto a pedido quanto a que ocorre quando cessam as causas que levaram o funcionário à aposentadoria ou à reforma, que depende da oportunidade e da conveniência da Administração.

Aliás, no âmbito federal não mais existe o instituto da readmissão, que o Estatuto da União definia como "o reingresso no serviço público do funcionário demitido ou exonerado, sem ressarcimento de prejuízos" (art. 62) O art. 113 do Decreto-lei 200 , de 25 de fevereiro de 1967, revogou expressamente os artigos 62 e 63 do Estatuto da União, bem como todas as disposições legais e regulamentares que disciplinavam as readmissões no serviço público federal. 
Desse modo, a única via que resta ao funcionário público para reingressar no serviço público, em decorrência de decisão administrativa ou judiciária, é a reintegração, porque, mesmo nas esferas estadual e municipal, em que existe ainda o instituto da readmissão, absurdo seria o agente, demitido ilegalmente, pleitear a volta "sem ressarcimento de prejuízo", quando a lei lhe faculta o reingresso "com ressarcimento das vantagens ligadas ao cargo"

\section{Conclusões.}

Cabe ainda referência ao artigo 65 do Código de Processo Penal que diz: "Faz coisa julgada no cível a sentença penal que reconhecer ter sido o ato praticado em estado de necessidade, em legítima defesa, em estrito cumprimento de dever legal ou no exercício regular de direito"

Repercute validamente, no âmbito administrativo, possibilitando a reintegração, a sentença penal absolutória que reconheça ter o ato do funcionário sido praticado: a) em estado de necessidade; b) em legítima defesa; c) em estrito cumprimento de dever legal; d) no exercício regular de direito.

Acolhida pelo juízo penal uma destas justificativas, o ato lesivo será, no âmbito administrativo, considerado lícito, o que não impede, entretanto, que, nos casos especiais de estado de necessidade e de legítima defesa, caiba reparação, a título de responsabilidade objetiva.

Em outras palavras, as autoridades administrativas que instauraram o processo administrativo, não poderão divergir do juiz do crime, afirmando que o fato não se deu em legítima defesa ou em estado de necessidade. Isso é inquestionável, mas, não obstante considerem provada a justificativa, casos admitirão de ressarcibilidade do dano, nos termos do artigo 107 , da Emenda Constitucional n. ${ }^{\circ}$ 1, de 17 de outubro de 1969.

O presente trabalho teve por finalidade pôr em relevo o problema da comunicabilidade dos juízos, penal e administra- 
tivo, procurando acentuar as hipóteses em que o funcionário, submetido a dois processos, tenha a oportunidade de voltar ao cargo, do qual fora ilegalmente afastado, mediante as portas largas do instituto da reintegração.

Ora, a reintegração é um direito subjetivo público do funcionário, oponível ao Estado. E a volta ao mesmo cargo com ressarcimento total pelos prejuízos advindos com a demissão.

Se o funcionário foi submetido apenas a processo administrativo, em virtude de infração administrativa, que configure ilícito administrativo, mas não chegue a capitular-se como crime, só lhe resta a exaustão da instância administrativa através do recurso administrativo hierárquico ou, então, o apelo ao Poder Judiciário, em procura de defeito formal do processo ou de inexistência real de motivo.

Se, porém, o funcionário foi também submetido a processo penal, porque a falta cometida configura ilícito penal, cumpre indagar a respeito do fundamento da sentença penal absolutória, cuja repercussão, na esfera administrativa, em certos casos, possibilita a reintegração do funcionário ao serviço público e no mesmo cargo.

O Código Civil, o Código Penal e o Código de Processo Penal fornecem elementos suficientes para o equacionamento e solução do problema.

As jurisdições civil, administrativa e penal são manifestações da soberania do Estado. Não devem opor-se. Ao contrário, devem ser harmônicas, servindo como referencial necessário a sentença penal.

Se, no âmbito penal, o juiz decidir, condenando, que houve o fato ou quem é seu autor, a sentença penal condenatória repercutirá no âmbito administrativo, obrigando à reparação do dano: "caberá ação regressiva contra o funcionário responsável, nos casos de culpa ou dolo" (Art. 107, § único)

Se, no juízo penal, o juiz decidir, absolvendo, concluindo pela inexistência do fato, pela falta de provas de autoria do 
fato ou pela existência do fato, mas sua desvinculação com o agente imputado, nesses casos haverá comunicabilidade de juízos, impondo-se a decisão penal sobre a decisão administrativa.

Ao contrário, havendo prova, insuficiente, ineficiente ou deficiente, não caberá a reintegração, porque restou um resíduo, um minus, um quantum, mas o bastante para a demissão do funcionário público, porque, não obstante tênue, a prova serviu para o delineamento do ilícito administrativo, em torno do qual gravitou o processo administrativo condenatório, que atingiu seu climax com a aplicação da pena de demissão.

Observe-se, por fim, que resíduo é não só o quantum de ilícito administrativo, que se agrega ao ilícito penal, sem com ele se confundir, como também é aquilo que restou do próprio ilícito penal quando, apreciado o fato Judiciário, foi o indiciado absolvido, em razão da deficiência probatória. No primeiro caso, o resíduo é um aliud, no segundo caso, é um minus; no primeiro caso, trata-se de resíduo heterogêneo, no segundo de resíduo homogêneo; nos dois casos, porém, resta o ilícito administrativo, bastante para a condenação administrativa. 